Acta medico-historica Rigensia (2010) IX:221-240

DOI: 10.25143/amhr.2010.IX.13

\title{
Доктор медицины Латвийского Университета Семен Комаров (1892-1964)
}

Константин Васильев, Арнис Виксна, Виктория Гарбузова

До сих пор нет подробной биографии Семена Андреевича Комарова, хотя некоторые сведения можно почерпнуть из отдельных публикаций. Ему посвящена информация в юбилейных сборниках, изданных к 10-летию и 20-летию Латвийского Университета. Опубликованы его некрологи в американских журналах. Очень краткие сведения о нем находятся в библиографии некрологов "Незабытые могилы" и в биографическом словаре "Русские в Северной Америке", которые составлены только на основе маленького некролога в Нью-йоркской газете "Новое Русское Слово" (1964, 2 апреля), содержащего неточности.

Библиография опубликованных трудов С. Комарова приведена в юбилейном сборнике Латвийского Университета (до 1929 г.), в белградском библиографическом справочнике (за 1931-1939 гг.) и при одном из некрологов (1966). Список работ С. Комарова уточнен и дополнен просмотром Index Medicus за 1920-1966 гг. Кроме того, был сделан сплошной просмотр харьковского журнала "Врачебное Дело" за 1921-1923 гг. После этого с большинством публикаций Семена Андреевича мы познакомились de visu. Его труды опубликованы на русском, немецком и английском языках. Немецкий вариант его фамилии - S. A. Komarow, английский $-S$. A. Komarov, а латышский (в Риге он жил и работал в 1920-х годах) - S. Komarovs.

Семен Комаров родился 24 мая/5 июня 1892 г. в Луганске Екатеринославской губернии (ныне Украина) в семье мещанина. Среднее образование получил в Луганской гимназии, которую окончил в 1910 г. с золотой медалью. В этом же году поступил в Военно-медицинскую академию в Петербурге. Здесь он слушал лекции по физиологии у знаменитого И. П. Павлова, который оказал на него большое влияние. Не случайно то, что, став уже опытным физиологом и будучи человеком в возрасте, в далеких Соединенных Штатах Америки, по воспоминанию сотрудников Научно-исследовательского института Фэлса, одним из его первых действий было приклеивание на стене 
его лаборатории текста известного завещания молодым ученым Павлова, слова которого С. Комаров знал наизусть. (После смерти Комарова завещание Павлова продолжало висеть на той же стене.) Также надо отметить, что в своих исследованиях С. Комаров использовал экспериментальную хирургическую методику, которой славилась школа Павлова и которой он прекрасно владел, продемонстрировав имеющиеся способности, усовершенствовав свищ пищевода у собак для естественного питания. Биографы Комарова отмечают, что влияние школы Павлова на него заключалось и в том, что он глубоко проникся идеей планирования, тщательного, повторного наблюдения и регистрации данных. Кроме того, в 1930-1942 гг. С. Комаров работал у Б. П. Бабкина, который являлся учеником Павлова, таким образом и через проф. Бабкина сказалось на нем влияние школы Павлова.

Какие-то обстоятельства заставили его в 1913 г., после третьего курса, уехать из столицы в Юрьев (ныне Тарту, Эстония), чтобы в местном университете продолжить свое медицинское образование. В том же году он перебрался поближе к своему родному городу, поступив в Харьковский университет. Выдержав государственные экзамены при Харьковском университете, С. Комаров 15 сентября 1915 г. получил звание лекаря с отличием (cum exima laude). После этого был избран сверхштатным ассистентом Кафедры медицинской химии Харьковского университета (1 октября 1915 г.). С 1 сентября 1919 г. избран старшим ассистентом при той же кафедре, где действовал по 1922 г. С июля 1916 г. по февраль 1920 г. был также лаборантом при Кафедре медицинской химии Харьковского женского медицинского института. Обе кафедры - в университете и в институте - возглавлял профессор Роберт Кримберг (1874-1941).

Во время пребывания в Харьковском университете С. Комаров по предложению проф. Кримберга занимался изучением действия физиологически активных веществ мышечной ткани. Эти исследования он продолжил у того же проф. Кримберга в Риге (1922-1929).

Захват власти большевиками в Российском государстве и как следствие Гражданская война и последующая разруха, установление тоталитарного режима, вынуждали интеллигенцию эмигрировать. Так принял предложение возглавить Кафедру физиологии и физиологической химии в Латвийском Университете проф. Кримберг, и в 1920 г. он возвращается на родину. Надо считать, что благодаря его хлопотам его харьковский ученик и сотрудник С. Комаров не только получил с 1 апреля 1922 г. место прозектора при Кафедре физиологии Латвийского Университета, но, самое главное, смог выехать из Советской Украины. Антипатия и неприятие коммунизма сохранилась у С. Комарова до конца жизни.

Проф. Кримберг был сторонником теории эндогенной (эндокринной) регуляции деятельности желез желудочно-кишечного тракта. В Харькове одному из своих учеников - А. П. Корхову (1882-1937) - он предложил 
исследовать степень и механизм воздействия физиологически активных веществ, полученных из мышц (карнозин, карнитин и метилгуанидин) на функцию желудка. (Тема диссертации - "Материалы к вопросу о желудочных секреторных гормонах мышечной ткани").

В отличие от Корхова, который исследовал действие указанных веществ на желудок, С. А. Комаров исследовал кишечник. Первоначальная его тема - влияние экстрактивных веществ мышечной ткани на секреторную деятельность железистого аппарата тонких кишок (объект исследования нормальная слизистая оболочка кишки оперированной соответствующим образом собаки). Впрочем, в ходе работы он вышел за рамки указанной темы. В лабораториях проф. Кримберга в Харьковском и Латвийском университетах он собрал большой фактический материал не только по вопросу о влиянии продуктов жизнедеятельности нормальной мышечной ткани (карнозин, гистидин, карнитин и метилгуанидин) на секрецию кишечного сока, но и о влиянии их на секрецию желудочного сока, а также о влияние составных частей мышечной ткани на секрецию панкреатического сока, желчи и слюны. При этом он пришел к выводу, что в нормальной мышечной ткани высших животных содержатся вещества, которые по их действию на железы пищеварительного аппарата могут быть названы "секреторными гормонами", что соответствовало концепции проф. Кримберга, который в своих работах неоднократно подчеркивая, что каждая живая клетка продуцирует в процессе жизнедеятельности различные "гормоны", особое внимание обратил на то обстоятельство, что именно мышечная ткань является источником весьма активных "гормонов", вырабатываемых этой тканью в больших количествах [1-9]. Здесь необходимо дать разъяснение о том, что в ту эпоху проводились многочисленные исследования о физиологической активности по отношению к изолированному сердцу, кровяному давлению, нервам и т. д. веществ, полученных из различных органов и тканей. Причем исследования эти трактовались как материалы к учению о гормонах.

В Риге Кримберг и Комаров выделили метилгуанидин и карнитин из крови, мочи и из определенных мышц. Было установлено, что эти вещества стимулируют желудочно-кишечную секрецию, хотя проведение исследований осложнялось тем, что введение самого сильного "мышечного экстракта" метилгуанидина - сопровождались сильной интоксикацией [10-15].

На заседании Медицинского факультета Латвийского Университета 19 мая 1926 г. С. Комаров успешно защитил диссертацию доктора медицины Zur Frage nach dem Mechanismus der Darmsekretion. В основу диссертации легла серия статей под таким же общим заглавием [5-7, 9], а официальными оппонентами были профессора фармаколог Цезарь Амслер (1881-1965), патолог Эрнест Паукул (1872-1941) и, согласно установленному на факультете порядку, научный руководитель его Р. Кримберг. В 1928 г. С. Комаров был принят в латвийское подданство. Став старшим ассистентом, в Латвийском 


\section{К. Васильев, А. Виксна, В. Гарбузова}

Университете он проработал до 1 декабря 1929, после чего попросил выдать ему удостоверяющие документы на английском языке. Казалось, что его положение упрочнилось и оставалось только продолжать работу в том же университете. Поэтому несколько неожиданно выглядит то, что после переписки с проф. Бабкиным он принимает решение перебраться к последнему в Канаду, в Монреаль, в тамошний Университет Мак-Гилл (McGill). В Риге С. Комаров проживал на ул. Пулквежа Бриежа, д. 7, который сохранился до наших дней.

Борис Петрович Бабкин (1877-1950) - ученик проф. И. П. Павлова, под руководством которого подготовил докторскую диссертацию. Он возглавлял Кафедру физиологии на Медицинском факультете Новороссийского университета в Одессе (этот факультет украинская советская власть в 1920 г. выделила в отдельный вуз, который первоначально именовался академией, а затем Одесским Медицинским институтом). В 1922 г. в числе большой группы интеллигенции советской России и советской Украины - около 200 человек - без всякого суда, одним лишь решением ГПУ, был выслан из страны. В описываемое время он работал в Университете Мак-Гилл.

Можем только предполагать, что побудило С. Комарова уехать из Риги. Возможно, что молодой Латвийский Университет в сравнении с Университетом Мак-Гилл казался провинциальным научным центром с одной стороны, а с другой нельзя не забывать, что Семен Андреевич, покинув родные места, переехав из одной страны в другую, а это был сознательный его выбор, не был привязан накрепко к месту своего нового жительства.

С 1930 г. С. Комаров ассистент отдела экспериментальной медицины Университета Мак-Гилл, а в 1939-1942 гг. лектор Кафедры физиологии того же университета. В 1935 г. в этом же университете защитил диссертацию на степень доктора философии (физиология). После этого при своей фамилии указывал две ученые степени - полученные как в Риге, так и в Монреале: M. D. и Ph. D.

К монреальскому периоду жизни Комарова приходится его женитьба на Ольге Петровской (5 июня 1937 г.). Она работала техником в лаборатории Бабкина. Она стала не только его супругой, но и помощницей в научной работе, участвуя в научно-исследовательских проектах мужа, и не случайно имеются совместные их публикации. Ее спокойная деловитость была идеальным расслабляющим средством на резкую реакцию Семена Андреевича по поводу любых помех в работе. Именно Ольга устраняла проблемы повседневной жизни и помогла супругу преодолеть природную застенчивость. Именно только благодаря тому, что она была рядом, он соглашался ездить и участвовать в работе различных научных форумов. Она оставалась его самым ценным сотрудником, секретарем и доверенным лицом (наперсником) до самой его смерти. Его последние слова были сказаны на русском языке, их могла понять только она. 
Работа под руководством проф. Бабкина способствовала тому, что направление научной деятельности С. Комарова меняется.

Но в первые годы пребывания С. Комарова в Канаде его работы включали исследования в области сравнительной биохимии и физиологии, которые являлись логическим продолжением той тематики, которая проводилась в лаборатории проф. Кримберга. В Университете МакГилл и в течение нескольких летних периодов на Атлантической биологической станции (Atlantic Biological Station) в заливе Фанди (Fundy) в Сент-Эндрю (St Andrew), Нью-Брансуике (New Brunswick) C. Комаров проводил исследования в области биохимии мышц говядины, рыб и омара. Это была новаторская попытка установить связь желудочных повышающих секрецию фракций, содержащихся в этих продуктах, к их диетической ценности. Он также сделал важное открытие о том, что кожа пикши (haddock), сельди и других рыб обладала выраженной желудочной деятельностью, повышающей секрецию, и обратил внимание на возможное клиническое применение данной информации. С. Комаров также сделал важный вклад в наше знание желудочных секреторных механизмов у пластинчатожаберных рыб, таких как акула, морская собака и скат. Комаров идентифицировал кислоту желудочной секреции как хлористоводородную и установил, что концентрации мочевины в желудочном соке и крови оказались одинаковыми $[16,17,20,21,23]$.

В статье 1938 г., а также в последующих своих публикациях С. Комаров предоставил первые убедительные доказательства того, что гастрин не является гистамином, как в то время многие считали, а есть полипептид $[29,43$, 44]. Его работы явились основой для последующих исследований, которые в конце концов привели к изолированию химической идентификации и синтезу гастрина Грегором (Gregory) и его коллегами.

Ряд его исследований посвящен изучению желудочного муцина и мукопротеидов. Уже в 1932 г. появляется совместная его с проф. Бабкиным первая публикация на данную тему. Несколько лет спустя Комаров сделал важное наблюдение. Измененная мнимым кормлением желудочная секреция была в 4-10 раз богаче белком и азотом, чем стимулируемый гистамином желудочный сок. Это навело Комарова на мысль о том, что секреция желудочных протеинов находится под сильным вагусным влиянием.

В течение нескольких лет Комаров собирал данные по тесной зависимости кислотных желудочных мукопротеидов от пепсина. Он обнаружил сходство между составом растворенного муцина и препаратами пепсина. Позже ему не удалось найти прозрачный (кристаллический) пепсин в желудочном соке, и он считал, что пепсин, также как и желудочный сок, не встречается в несвязанной форме, а только как часть комплекса с мукопротеидом. Это свидетельствовало о существовании ряда белков и мукопротеидов в желудочном соке у собаки и о максимальном содержании кислого желудочного протеина, содержащего пепсин, гексозамин и уроновую кислоту. 


\section{К. Васильев, А. Виксна, В. Гарбузова}

Еще в лаборатории Бабкина Комаров изучал ингибирующее воздействие муцина на пищеварительную деятельность, которая, по его мнению, была эффективной для предотвращения самопереваривания желудочной мукозы ввиду наличия мукоитиновой серной кислоты. Еще одним важным вкладов Комарова в проблему мукопротеидов была косвенная демонстрация наличия, как минимум, двух различных мукопротеидов в желудочном соке. Один из них он назвал мукопротеид-1 или кислый мукопротеид, содержащий сульфаты и уремическую кислоту; а второй он назвал мукопротеид-2 или нейтральный мукопротеид, содержащий большое количество гексозамина, но немного уремической кислоты.

Им был разработан метод для количественного определения желудочного муцина в отношении содержания уремической кислоты, что вполне подходило для анализа кислых мукопротеидов. Комаров продолжал заниматься желудочными мукопротеидами вплоть до 1953 г., когда он выступил со своим последним обозрением по этому предмету на Национальной желудочно-кишечной конференции по проблеме рака. Он акцентировал внимание на сложности желудочных мукопротеидов, множестве их происхождений. Его цитирование утверждения проф. Бабкина по этому поводу подчеркивает его неослабевающий интерес к мукосубстанциям, которые в то время были проигнорированными многими исследователями: "Все-же слизь - это очень реальная вещь, столь же реальная, как и сам желудочный сок." $[18,19,26,28,30,50,51,53,56,59,61,64,67,68,74,81]$.

В начале 1940-х годов из-под пера С. Комарова вышло несколько работ о пепсине. Утверждения, что пепсин, фактически, один из существенных элементов в генезе пептической язвы и что слизь могла бы защитить слизистую оболочку желудка либо как физическое вещество или как химическое антипепсиновое вещество, он показал более превосходящие свойства гели гидроокиси алюминия в сравнении с карбонатом натрия, и с тех пор он широко используется [38, 41, 42, 45].

Тогда же появились первые публикации С. Комарова о желудочной секреции у собак. Изучение им желудочной секреции у собак отражает его мастерство в экспериментальном планировании и его технику. Им приведены убедительные доказательства того, что гидроокись алюминия в желудке не только нейтрализует кислоту в полости желудка, но и задерживает кислотнопепсиновую секрецию в изолированном желудочке, иннервированном блуждающим нервом. Клиницисты отдали должное затронутой проблеме. Им было проверено действие активированного эргостерола, экстракта паращитовидной железы и внутривенного кальция на стимулируемую мясом желудочную секрецию в изолированном желудочке, иннервированном блуждающим нервом. Было отмечено уменьшение кислотно-пепсиновой реакции (уменьшение секреции соляной кислоты и пепсиногенов) $[34,37$, $88,90-92,94]$. 
В 1942 г. С. Комаров переезжает в США. Он занял должность руководителя по химии медицинской научно-исследовательской лаборатории Фонда Фэлса (Fels Fund) Медицинской школы университета Темпл (Temple University school of Medicine) в г. Филадельфия (штат Пенсильвания). В 1947-1964 гг. он руководитель по экспериментальной физиологии в Научноисследовательском институте Фэлса там же. Тематика научных работ С. Комарова в Филадельфии явилась естественным продолжением того, чем он занимался в Монреале. Так, в университете Темпл им были продолжены исследования о желудочных белках и мукопротеидах, о пепсине, о желудочной секреции у собак (см. выше).

И изучение физиологии панкреатической железы С. Комаров начал еще в Университете Мак-Гилл - первые две публикации в 1939 г. Вполне возможно, что он заинтересовался этой проблемой ввиду разных точек зрения его учителей - И. П. Павлова и Б. П. Бабкина. Павлов предложил теорию целевой адаптации пищеварительных желез, для которой необходимо, чтобы поджелудочная железа выделяла различные ферменты (протеазы, амилазы и липазы) в переменных пропорциях в зависимости от типа пищи, подвергаемой перевариванию. Экспериментальные результаты Бабкина показали, что ферменты выделяются в параллельной концентрации (т. е., количество выделяемых ферментов не зависит от вида пищи). Комаров доказал, что оба были неправы, хотя Бабкин был намного ближе к истине, чем Павлов. Комаров понимал, что ошибки прошлого были результатом неточных методов. Он поставил задачу усовершенствовать имеющиеся методы и разработать новые для определения деятельности трех главных ферментных систем. Он изменил существующие методы определения амилазы и протеазы и разработал новый метод для липазы.

Он доказал тот факт, что хотя три этих фермента и имели тенденцию к изменению концентрации в одном и том же направлении, но были и статистические существенные различия в относительной концентрации среди этих трех ферментов в различных образцах сока одного и того же животного и между любым из них. Параллельная секреция ферментов, следовательно, носила только относительный характер. Комаров также доказал, что не было никакой значимой связи между концентрацией какого-либо фермента и наличием его субстрата в перевариваемой пище. Таким образом, не существует никакой целевой адаптации выделяемого фермента к виду пищи. Тем самым был положен конец полувековым разногласиям, а самая большая практическая ценность работы С. Комарова по проблеме поджелудочной железы заключается, вероятно, в его вкладе в методологию, особенно в его настойчивости на статистически проверенной точности в определении ферментативной активности [32, 33, 45, 71, 76, 78, 79, 82-87].

Другие исследования включают электрофоретический анализ протеина панкреатического сока и исследования ферментов сыворотки при остром 
панкреатите. При электрофоретическом исследовании было выявлено неожиданное многообразие в спектре панкреатических ферментов и открылись новые области для исследования [75, 77, 80, 89].

В 1944 г. появилась первая публикация С. Комарова, посвященная желудочной физиологии крыс. С тех пор на многие годы он стал ведущим исследователем, использующим крысу для экспериментального исследования желудочной патологии. Его привлекала возможность при использовании этого животного проводить эксперименты с большими партиями для статистического анализа. Он предложил различные средства сбора желудочного сока применительно к новой технике и с учетом трудностей. В 1944 г. он описал острый желудочный свищ, который включал лигатуру пилоруса и фистулу кардиального отдела желудка, сросшегося с кожей. Животное поддерживалось под легкой анестезией в течение целого периода сбора материала, который мог длиться от 24 до 72 часов. В 1945 г. Комаров вместе c X. Шеем (H. Shay) продемонстрировали то, что секрет можно собрать в желудке непосредственно после простой лигатуры пилоруса. Животному не давали наркоз во время периода сбора материала, который длился от 16 до 18 часов и мог привести к образованию язв. Позже техника стала очень популярной, когда период сбора материала был сокращен до нескольких часов. Еще в 1945 г. Комаров обратил внимание на факторы, которые дают более однородные результаты: исключение из партии желудочных соков образцы, содержащие следы пищи; выражение секреторного объема в единицах объем/100 г массы тела. Начиная с 1947 г. он использовал вариант своей техники, при которой наряду с лигатурой пилоруса была использована лигатура пищевода с эзофагостомией над лигатурой. В 1963 г. он сообщил о результатах, полученных при хронической фистуле у крыс. Эта техника, которая позволяет собрать желудочный сок у одного и того же животного несколько раз, была усовершенствована одновременно в нескольких лабораториях. Особые свойства техники Комарова заключались в использовании очень короткой и очень легкой полой иглы (канюли). Полая игла помещается в кардиальный отдел желудка под левым рёберным краем. Эта модель позволяла использовать одного животного в эксперименте в течение нескольких месяцев.

Изучая базальную секрецию у крыс С. Комаров установил, что для этого животного характерна непрерывная кислотная секреция (желудочный сок выделяется у голодающего животного, даже когда пищеварительный тракт полностью пуст). Комаров продемонстрировал депрессивное действие анестезии метаном на примере базальной секреции и подчеркнул, что такое воздействие связано с торможением цефалического стимулирующего фактора. Он изучал вместе с С. П. Брелоу (S. P. Bralow) зависимость между поведением и уровнем секреции у крыс с хронической фистулой. С. Комаров изучал также влияние определенных эндокринных желез на примере базаль- 


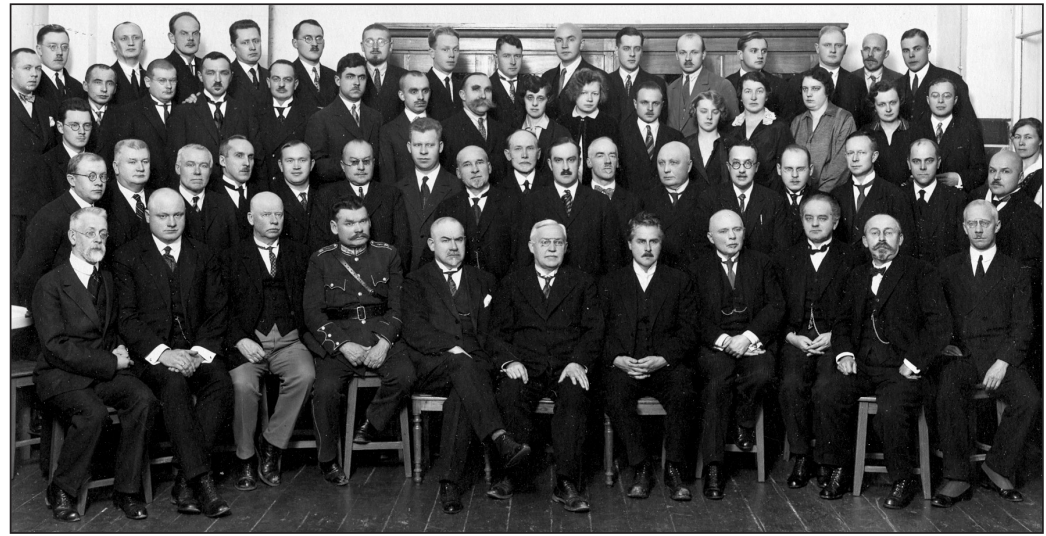

1. Профессорско-преподавательский состав Медицинского факультета Латвийского Университета в 1929 г. В первом ряду слева: В. Клименко, Х. Будул, Я. Дзирне. П. Сникер, Я. Руберт, Р. Кримберг, Ц. Амслер, Я. Алкснис, Р. Адельгейм, Э. Паукул, Э. Гартье. С. Комаров в третьем ряду справа крайний [Фототека Музея истории медицины им. П. Страдыня. № Fp 28963]

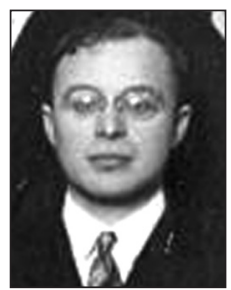

2-й портрет

С. Комарова из данного группового снимка, 1929 г.

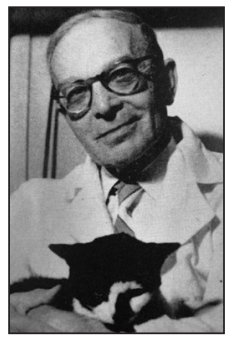

3-й портрет

С. Комарова из некролога, 1964 г.

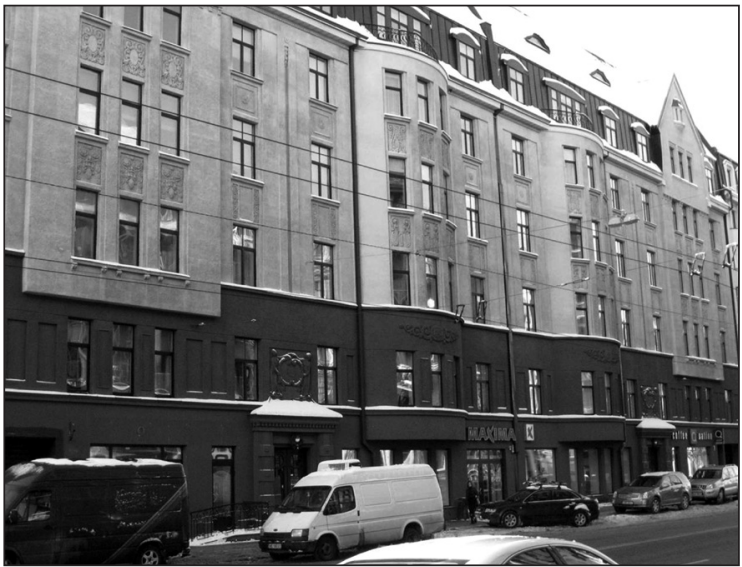

4. Дом в Риге, в котором проживал С. Комаров, на ул. Пулквежа Бриежа, д. 7. Снимок 2009 г. 
ной секреции, а именно с помощью хирургического или радиологического разрушения нарушал функции щитовидной железы или адреналэктомии с хронической фистулой у крыс. Он установил, что адреналэктомия приводит к экспоненциальному падению кислотной секреции, которое становится незначительным спустя 3-7 недель; секреция пепсина также снижается. Было изучено влияние на базальную секрецию различных лекарственных препаратов. Доказано, что гистамин оказывает незначительное воздействие на секрецию на крыс, в то время как гидрохлорид холина стимулирует ее. Инсулин усиливает кислотную секрецию у животного, а анестезия метаном оказывает ингибирующее действие. В 1944 г. С. Комаров установил стимулирующее действие препаратов гастрина. Наконец, он изучил влияние различных лекарственных препаратов на секрецию кислоты, в особенности алкилсульфатов, которые стимулируют секрецию слизи и, возможно, в зависимости от их концентрации, стимулируют или замедляют секрецию кислоты и пепсина. Язвообразующее действие пилорической лигатуры у крыс интересовало С. Комарова с 1945 г., когда он впервые опубликовал сообщение на эту тему. Вместе с X. Шеем (H. Shay) он подчеркнул ценность техники при определении антисекреторного или противоязвенного действия от применения различных веществ. Он изучил профилактическое действие алюминия, магния и алкилированных составов сульфата на язвах кардиального отдела желудка. Он обнаружил, что язвы образуются вследствие дефицита тиамина. Париетальная клеточная масса у крыс была предметом одного из самых последних исследований, выполненных Комаровым и С. П. Брелоу (S. P. Bralow). Было установлено, что у крысы размер париетальной клеточной массы прямо пропорционален возрасту. Таким образом, поскольку возраст крысы увеличивается с 30 до 112 дней, число париетальных клеток возрастает от 25 до 55 миллионов. Наконец, париетальная клеточная масса не уменьшается после адреналэктомии, несмотря на спад секреции. Работы С. Комарова с крысами имеет большую ценность для нашего знания желудочной физиологии и патологии, а техника, описанная им, стала широко известной и получила признание $[46,49,51,52,54,69,93,95-111,113]$.

В Канаде и в США С. А. Комаров многие годы был членом Канадского Физиологического общества, Американского Физиологического общества, Американской Гастроэнтерологической ассоциации.

Будучи педантичным экспериментатором, С. Комаров требовал от своих коллег такой же точности и ясности наблюдений. Его постоянная настойчивость и упорство часто не были поняты новыми коллегами. Со временем, однако, они принимали его позицию и соглашались с тем, что конечные результаты оправдывали усилия. Вряд ли кто другой мог так последовательно извлекать такое количество фактов из эксперимента, как это делал Комаров. Когда он убедился в эффективности статистических методов оценки его наблюдений, то продолжил свое обучение, чтобы стать специалистом в 
биомедицинской статистике. Его простым кредо была правда, полученная посредством тщательных наблюдений и анализа. Часто он просыпался между 5-ю и 6-ю утра, взволнованный какой-либо проблемой. И тогда он сидел часами, думая и закуривая одну сигарету за другой до тех пор, пока какое-то наблюдение можно было согласовать с другими известными фактами.

Это была неотъемлемая черта его характера, проявившаяся в том, что он настоял на знании правды о природе своей последней болезни - рак поджелудочной железы. Он принял это знание спокойно и сразу приступил ко всем необходимым приготовлениям на возможный случай. Во время заключительного периода его болезни были испытаны новые химиотерапевтические средства. Комаров начал проводить тщательные наблюдения и записывать свои персональные реакции на лекарственную терапию и считал это своим последним экспериментом. Когда понадобились сосудосуживающие вещества, чтобы вывести его из шока, он посмотрел в одну точку и сказал, что все усилия бесполезны, поскольку он умрет до полуночи. Как обычно, его наблюдения были точны, и он спокойно скончался в 10 часов вечера.

Семен Андреевич (или Симон Эндрю, как его называли в Америке) Комаров умер в медицинском центре университета Темпл г. Филадельфия 29 марта 1964 года.

\section{Опубликованные работы С. А. Комарова}

Komarow S. А. (нем.)/Komarov S. А. (анг.)/Komarovs Semjons (латыш.)

* - отмечены те публикации, с которыми de visu ознакомиться мы не смогли.

\section{Принятые сокращения:}

Amer. J. Physiol. - American Journal of Physiology.

Amer. J. Dig. Dis. and Nutr. - The American Journal of Digestive Diseases and Nutrition.

Amer. J. Dig. Dis. - The American Journal of Digestive Diseases. New Series.

Amer. J. Med. Sci. - The American Journal of the Medical Sciences.

Biochem. Zeitschr. - Biochemische Zeitschrift.

Canad. J. Research. - Canadian Journal of Research.

Canad. Med. Assoc. J. - Canadian Medical Association Journal.

Clin Res Proc. - Clinical Research Proceedings.

Contrib. Canad. Biol. and Fish. - Contributions to Canadian Biology and Fisheries. Gast. - Gastroenterology.

Fed. Proc. - Federation Proceedings. Published by Federation of American Societies for Experimental Biology.

J. Biol. Chem. - Journal of Biological Chemistry 


\section{К. Васильев, А. Виксна, В. Гарбузова}

J. Lab. and Clin. - The Journal of Laboratory and Clinical Medicine. St Louis. J. Nat. Cancer Inst. - Journal of the Nation Cancer Institute.

Pflüges Archiv - Archiv für die gesamte Physiologie des Menschen und der Tiere. Proc. Soc. Exp. Biol. and Med. - Proceedings of the Society for Experimental Revue Canad. Biol. - Revue Canadienne de Biologie.

\section{1}

1. Комаров С.А. К вопросу о гормонах мышечной ткани. Врачебное дело, 1921, № 1-6, Стб. 1-6; № 11-15, Стб. 104-112.

\section{2}

2. Комаров С.А. О механизме координации работы пищеварительного аппарата с потребностями организма и пищевыми раздражениями. Врачебное дело, 1922, № 3-6, Стб. 52-53.

3. Комаров С.А. Очередные проблемы физиологии пищеварения. Врачебное дело, 1922, № 3-6, Стб. 49-52.

4. Комаров С. А. О влиянии сахарина на желудочную и кишечную секрецию. Врачебное дело, 1922 [за 1922-1923 гг. в этом журнале мы не обнаружили].

\section{4}

5. Komarow S.A. Zur Frage nach dem Mechanismus der Darmsekretion. I. Mitteilung. Biochem. Zeitschr., 1924, Bd. 146, S. 122-143.

6. Komarow S.A. Zur Frage nach dem Mechanismus der Darmsekretion. II. Mitteilung. Biochem. Zeitschr., 1924, Bd. 147, S. 221-252.

7. Komarow S.A. Zur Frage nach dem Mechanismus der Darmsekretion. III. Mitteilung. Biochem. Zeitschr., 1924, Bd. 151, S. 467-490.

\section{6}

8. Komarow S.A. Ein sicheres Verfahren zur Anlegung der Oesophagusfistel. Pflüges Archiv., 1926, Bd. 212, S. 212-214.

9. Komarow S.A. Zur Frage nach dem Mechanismus der Darmsekretion. IV. Mitteilung. Biochem. Zeitschr., 1926, Bd. 167, S. 275-312.

10. Krimberg R., Komarow S.A. Über den Einfluss des Carnosins auf die Sekretionsarbeit der Magendrüsen. Biochem. Zeitschr., 1926, Bd. 176, S. 467-472.

11. Krimberg R., Komarow S.A. Über die Einwirkung des Methylguanidins auf die Absonderung des Pankreassaftes und der Galle. Biochem. Zeitschr., 1926, Bd. 176, S. 73-83.

12. Krimberg R., Komarow S.A. Weitere Untersuchungen über den Einfluss der sogenannten Carnosinfraktion des Fleischextraktes auf die Sekretion der Magendrüsen. Biochem. Zeitschr., 1926, Bd. 171, S. 169-176.

1927

13. Krimberg R., Komarow S.A. Über den Einfluss einiger Fraktionen des Fleischextraktes auf die Absonderung des Pankreassaftes und der Galle. Biochem. Zeitschr., 1927, Bd. 184, S. 442-452. 


\section{8}

14. Krimberg R., Komarow S.A. Untersuchungen über den Einfluss einiger basischen Fraktionen des Fleischextrakts auf die Sekretion der Magendrüsen. Biochem. Zeitschr., 1928, Bd. 194, S. 410-421.

\section{9}

15. Komarow S.A. Über das Vorkommen des präformierten Methylguanidins im Muskelgewebe. Biochem. Zeitschr., 1929, Bd. 211, S. 326-351.

\section{1}

16. Babkin B.P., Komarov S.A. Note on the urea content of the gastric juice in the scate. Contrib. Canad. Biol. and Fish., 1931, Vol. 7, p. 13.

17. Komarov S.A. Comparative study of gastric secretion in the dog after ingestion of haddock flesh and skin and of beef meat. Contrib. Canad. Biol. and Fish., 1931, Vol. 7, p. 59.

\section{2}

18. Babkin B.P., Komarov S.A. The influence of gastric mucus on peptic digestion. Canad. Med. Assoc. J., 1932, Vol. 27, p. 463-469.

19. Webster D.R., Komarov S.A. Mucoprotein as a normal constituent of the gastric juice. J. Biol. Chem., 1932, Vol. 96, p. 133-142.

\section{3}

20. Komarov S.A. The partition of non-protein nitrogen in haddock's muscle. Contrib. Canad. Biol. and Fish., 1933, Vol. 8, p. 125.

21. Komarov S.A. Note on the partition of non-protein nitrogen in autolysed haddock's muscle. Contrib. Canad. Biol. and Fish., 1933, Vol. 8, p. 133.

22. Komarow S.A. Über die Anwesenheit von sekretagogen Substanzen in dem reinen Magensaft des Hundes. Biochem. Zeitschr., 1933, Bd. 261, S. 92105.

23. Mackay-Sawyer M.E., Komarov S.A. Some physiological effects of extractive substaces in skate's skin. Contrib. Canad. Biol. Fish., 1933, Vol. 7, p. 441.

24. Vineberg A.M., Komarov S.A. Influence of vagus nerve on esophageal secretion. Amer. J. Physiol., 1933, Vol. 104, p. 73-80.

\section{4}

25. Komarov S. A. Presence of vitamin $\mathrm{B}_{1}$ in gastric juice. Proc. Soc. Exp. Biol. and Med., 1934, Vol. 32, p. 398-400.

1935

26. Komarov S.A. Isolation of mucoitin sulphuric acid from canine gastric juice. J. Biol. Chem., 1935, Vol. 109, p. 177-187.

\section{6}

27. Komarov S. A. The action of the nitrogenous bases of the gastric juice on blood pressure, pancreatic secretion and flow of bile. Amer. J. Physiol., 1936, Vol. 115, p. 604-609.

28. Komarov S. A. The influence of mucoitin sulfuric acid on peptic digestion. Amer. J. Dig. Dis. and Nutr., 1936, Vol. 3, p. 164-166. 


\section{К. Васильев, А. Виксна, В. Гарбузова}

\section{8}

29. Komarov S.A. Gastrin. Proc. Soc. Exp. Biol. and Med., 1938, Vol. 38, p. 514516.

30. Komarov S.A., Day J.J. The partition of nitrogen in canine gastric juice. J. Lab. and Clin. Med., 1938, Vol. 23, p. 822-832.

\section{9}

31. Komarov S.A. Glucose and gastric secretion. Amer. J. Dig. Dis., 1939, Vol. 6, p. 169-175.

32. Komarov S.A., Langstroth G.O., McRae D.R. The secretion of crystalloids and protein material by the pancreas in response to secretin administration. Canad. J. Research., 1939, Vol. 17, p. 113-123.

33. Langstroth G.O., McRae D.R., Komarov S. A. The synthesis and secretion of protein material by the pancreas. Canad. J. Research., 1939, Vol. 17, p. 137149.

\section{0}

34. Babkin B.P., Komarov O., Komarov S.A. The effect of activated ergosterol and of parathyroid hormone on gastric secretion in the dog. Endocrinology. 1940, Vol. 26, p. 703-715.

35. ${ }^{\star}$ Komarov O., Komarov S.A. Effect of olive oil and of cod liver oil on gastric secretion in dog. Canad. M.A.S., 1940, Vol. 43, p. 129-133.

36. Komarov S.A., Stavraky G.W. Nitrogenous constituents of cat's submaxillary saliva evoked by parasympathetic and sympathetic stimulation. Canad. J. Research., 1940, Vol. 18, p. 233-247.

37. Komarov S.A., Krueger L. The effect of aluminum hydroxide gel on gastric secretion in the dog. Amer. J. Dig. Dis., 1940, Vol. 7, p. 170-175.

38. Komarov S.A., Komarov O. The precipitability of pepsin by colloidal aluminum hydroxide. Amer. J. Dig. Dis., 1940, Vol. 7, p. 166-169.

39 Schiffrin M.J., Komarov S.A. The inactivation of pepsin by compounds of aluminum and magnesium. Amer. J. Dig. Dis., 1940, Vol. 7, p. 170-175.

\section{1}

40. Babkin B.P., Komarov S.A. The effect of secretin on the concentration of pepsin in the gastric juice. Proc. Roy. Soc. Canada., 1941, Vol. 35, p. 206.

41. Schiffrin M.J., Komarov S.A. The inactivation of pepsin by compounds of aluminum and magnesium. Amer. J. Dig. Dis., 1941, Vol. 8, p. 215-217.

\section{2}

42. Komarov S.A. The inactivation of pepsin and its relation to peptic ulcers. The Review of Gastroenterology., 1942, Vol. 9 p. 165-175.

43. Komarov S.A. Studies on gastrin. I. Methods of isolation of a specific gastric secretagogue from the pyloric mucous membrane and its chemical properties. Revue Canad. Biol., 1942, Vol. 1, p. 191-205. 
44. Komarov S.A. Studies on gastrin. II. Physiological properties of the specific gastric secretagogue of the pyloric mucous membrane. Revue Canad. Biol., 1942, Vol. 1, p P. 377-401.

\section{4}

45. Babkin B.P., Komarov S.A. The effect of secretin on the concentration of pepsin in gastric juice. Revue Canad. Biol., 1944, Vol. 3, p. 344-356.

46. Komarov S.A., Shay H., Rayport M., Fels S.S. Some observations on gastric secretion in normal rats. Gast., 1944, Vol. 3, p. 406-413.

47. Shay H., Komarov S.A., Siplet H., Fels S. Role of liver and gallbladder in excreion in dog of some of hewer sulfonamides. Gast., 1944, V. 2, p. 432436.

\section{5}

48. Kolm R., Komarov S.A., Shay H. Experimental studies on excretion of neutral red by stomach. Gast., 1945, Vol. 5, p. 303-319.

49. Shay H., Komarov S.A., Fels S.S., Merance D.R., Gruenstein M., Siplet H. A simple method for the uniform production of gastric ulceration in the rat. Gast., 1945, Vol. 5, p. 43-61.

\section{6}

50. Shay H., Komarov S.A., Siplet H., Fels S.S. A gastric mucigogue action of the alkyl sulfares. Science., 1946, Vol. 103, p. 50-52.

51. Shay H., Komarov S.A., Siplet H., Gruenstein M. The effect of the alkyl sulfates on gastric secretion in the rat. Amer. J. Med. Sci., 1946, Vol. 211, p. 245. (Abst.)

52. Shay H., Komarov S.A., Gruenstein M., Fels S.S. The effect of thiamin deprivation upon gastric secretion in rats. Gast., 1946, Vol. 6, p. 199-212.

\section{7}

53. Komarov S.A., Siplet H., Shay H. Gastric mucin: A new quantitative method for its determination. Secretion of mucin under various conditions. Fed. Proc., 1947, Vol. 6, p. 144-145. (Abst.)

54. Shay H., Komarov S.A., Siplet H., Gruenstein M. Evaluation of some antacid and antipeptic agents in prevention of gastric ulceration in rat. Amer. J. Dig. Dis., 1947, Vol. 14, p. 99-104.

55. Shay H., Komarov S.A., Siplet H. Inhibitory effect of sodium dodecyl sulfate upon gastric secretary response to histamine. Science., 1947, Vol. 105, p. $128-129$.

\section{8}

56. Komarov S.A., Shay H., Siplet H. Secretion of mucin in response to sham feeding and histamine stimulation. Fed. Proc., 1948, Vol. 7, p. 67. (Abst.)

57. Thomas J.E., Komarov S.A. Physiological aspects of vagotomy. Gast., 1948, Vol. 11, p. 413-418. 


\section{К. Васильев, А. Виксна, В. Гарбузова}

58. Shay H., Gruenstein M., Siplet H., Komarov S.A. Protection of gastric mucosa of rat against ulceration by prefeeding with protein hydrolysates. Proc. Soc. Exp. Biol. and Med., 1948, Vol. 69., p. 369-373.

59. Siplet H., Komarov S.A., Shay H. The estimation of mucin in gastric juice. J. Biol. Chem., 1948, Vol. 176, p. 545-561.

1949

60. Edwards L.E., Kolm R., Komarov S.A., Shay H. Quantitative determination of neutral red in rat blood and plazma. Revue Canad. Biol., 1949, Vol. 8, p. 280-284.

61. Grossberg A., Komarov S.A., Shay H. Mucoproteins of gastric juice and mucus and the mechanism of their secretion. Fed. Proc., 1949, Vol. 8, p. 62. (Abst.)

62. Kolm R., Komarov S.A., Shay H. Quantitative determination of neutral red in gastric juice and gastric contents. Revue Canad. Biol., 1949, Vol. 8, p. 262-279.

63. Komarov S.A., Kolm R., Shay H. Excretion of neutral red by live, kidneys and stomach. Revue Canad. Biol., 1949, Vol. 8, p. 285-297.

64. Komarov S.A., Shay H., Siplet H. Secretion of gastric mucin in response to sham feeding and histamine stimulation. Amer. J. Physiol., 1949, Vol. 158, p. 194-200.

65. ^Shay H., Aegerter E.A., Gruenstein M., Komarov S.A. Development of adenocarcinoma of breast in Wistar rat following gastric instillation of methylcholanthrene. J. Nat. Cancer Inst., 1949, Vol. 10, p. 255-266.

66. Shay H., Komarov S.A. Gruenstein M. Effects of vagotomy in rat. Arch. Surd., 1949, Vol. 59, p. 210-226.

1950

67. Grossberg A.L., Komarov S.A., Shay H. Mucoproteins of gastric juice and mucus and mechanism of their secretions. Amer. J. Physiol., 1950, Vol. 163,. 136-146.

68. Grossberg A.L., Komarov S.A., Shay H. Study of protein fractions of gastric juice obtained by electrophoretic separation. Fed. Proc., 1950, Vol. 9, p. 52. (Abst.)

69. Komarov S.A., Shay H., Siplet H., Gruenstein M. A study of the effects and mechanism of action of sodium dodecyl sulphate on gastric secretion in rats. British Journal of Pharmacology and Chemotherapy, 1950, Vol. 5, p. 1-8.

70. Komarov S.A., Friedman M.H.F. B.P. Babkin, 1877-1950. Gast., 1950, Vol. 16, p. 511-514.

71. Komarov S.A., Siplet H., Shay H. Protein content and tryptic activity determined by several methods in canine pancreatic juice under different conditions of stimulation. Fed. Proc., 1950, Vol. 9, p. 72. (Abst.)

72. Lorber S.H., Komarov S.A., Shay H. Effect of sham feeding on gastric motor activity of dog. Amer. J. Physiol., 1950, Vol. 162, p. 447-451. 
73. Shay H., Komarov S.A., Berk J.E. Some fallacies in clinical measurement of gastric acidity with special reference to histamine test. Gast., 1950, Vol. 15,

\section{1} p. 110-117.

74. Grossberg A.L., Komarov S.A., Shay H. Proteins of canine gastric juice. Electrophoretic characterization and separation of tractions. Amer. J. Physiol., 1951, Vol. 165,. 1-9.

75. Komarov S.A., Grossberg A.L. Protein constituents of canine pancreatic juice: Electrophoretic and enzymatic studies. Fed. Proc., 1951, Vol. 10, p. 74. (Abst.)

\section{2}

76. Guth P., Komarov S.A., Shay H. Phototurbidimetric determination of pancreatic amylase. Fed. Proc., 1952, Vol. 11, p. 61 (Abst.)

77. Grossberg A.L., Komarov S.A., Shay H. Distribution of proteins and enzymatic activities in electrophoretic components of canine pancreatic juice. Amer. J. Physiol., 1952, Vol. 168, p. 269-282.

\section{3}

78. Grossberg A., Guth P., Komarov S.A., Shay H. A phototurbidimetric method for determination of lipase in canine pancreatic juice. Revue Canad. Biol., 1953, Vol. 12, p. 495-508.

79. Guth P., Komarov S.A., Shay H. Phototurbidimetric determination of pancreatic amylase. Amer. J. Physiol., 1953, Vol. 173, p. 461-466.

80. Komarov S.A., Shay H., Zislin C. Lipolytic activity of human blood serum: Method for its determination and its possible relation to pancreatic lipase. Fed. Proc., 1953, Vol. 12, p. 502. (Abst.)

81. Komarov S.A. Mucoproteins of gastric secretion. J. Nat. Cancer Inst., 1953, Vol. 13, p. 1007-1012.

82. Shay H., Komarov S.A., Siplet H., Lorber S.H. Effect of pancreatic duct ligation and induced acute pancreatitis on serum alkaline phosphatase in dogs. Gast., 1953, Vol. 23, p. 460-469.

83. Shay H., Komarov S.A., Siplet H., Lorber S.H. Serum alkaline phosphatase. Studies in experimental acute pancreatitis. Clin. Res. Proc., 1953, Vol. 1, p. 57.

1954

84. Komarov S.A., Siplet H., Shay H. Correlation of proteolytic activity of canine pancreatic secretion with its protein nitrogen content. Amer. J. Med. Sci., 1954, Vol. 227, p. 359-360. (Abst.)

85. Komarov S.A., Siplet H., Shay H. Style C.Z. Relation of proteolytic and lipolytic activity of canine pancreatic secretion to protein nitrogen content. Fed. Proc., 1954, Vol. 13, p. 81. (Abst.) 


\section{К. Васильев, А. Виксна, В. Гарбузова}

\section{5}

86. Komarov S.A., Siplet H., Shay H., Guth P.H. Relation between proteolytic activity and protein nitrogen of canine pancreatic juice. Amer. J. Physiol., 1955, Vol. 183, p. 495-509.

\section{6}

87. Guth P.H., Komarov S.A., Shay H., Style C.Z. Relationship between protein nitrogen, proteolytic, amylolytic and lipolytic enzymes in canine pancreatic juice obtained under various conditions of stimulation. Amer. J. Physiol., 1956, Vol. 187, p. 207-223.

1957

88. Marks I.N., Komarov S.A., Shay H. Acid secretory responses following histamine stimulation and relationship between "maximum asid output" and number of parietal cells. Fed. Proc., 1957, Vol. 16, p. 83. (Abst.)

1958

89. Guth P.H., Komarov S.A., Shay H., Style C.Z. Pancreatic lipase - determination in canine pancreatic secretio and human blood serum. Amer. J. Physiol., 1958, Vol. 192, p. 1-13.

90. Marks I.N., Komarov S.A., Shay H. Acid secretory responses to histamine and the parietal cell mass in the dog. Amer. J. Physiol., 1958, Vol. 195, p. 528-534.

91 Marks I.N., Komarov S.A. Gastric secretory responses to graded doses of histamine in dogs with gastric fistula and esophagostomy. Fed. Proc., 1958, Vol. 17, p. 104. (Abst.)

1959

92. Marks I.N., Komarov S.A. and Shay H. Further observations on the effect of mecholyl and histamine on gastric secretion. Fed. Proc., 1959, Vol. 18, p. 385. (Abst.)

\section{0}

93. Bralow S.P., Komarov S.A., Shay H. Relationship of parietal cell mass to age and weight in normal Wistar rats. Physiologist, 1960, Vol. 3, p. 27. (Abst.)

94. Marks I.N., Komarov S.A. and Shay H. Maximal acid secretory response to histamine and its relation to parietal cell mass in the dog. Amer. J. Physiol., 1960, Vol. 199, p. 579-588.

\section{1}

95. Bralow S.P., Komarov S.A., Shay H. Influence of urethane anesthesia on the effect of insulin hypoglycemia on gastric secretion in chronic fistula rats. Fed. Proc., 1961, Vol. 20, p. 250. (Abst.)

\section{2}

96. Bralow S.P., Komarov S.A. Parietal cell mass and distribution in stomachs of Wistar rats. Amer. J. Physiol., 1962, Vol. 203, p. 550-552.

97. Bralow S.P., Komarov S.A. Parietal cell mass and distribution of parietal cells in glandular mucosa during normal growth in Wistar rats. Amer. J. Med. Sci., 1962, Vol. 243, p. 679. (Abst.) 
98. Bralow S.P., Komarov S.A. Studies of parietal cell mass in rats. Part II: Distribution of parietal cells in glandular mucosa during growth. Fed. Proc., 1962, Vol. 21, p. 255. (Abst.)

99. Komarov S.A., Bralow S.P., Shay H., Boyd E. Relationship between gastric secretion and behavior in chronic fistula rats. Fed. Proc., 1962, Vol. 21, p. 263. (Abst.)

100. Komarov S.A., Bralow S.P., Shay H., Boyd E. Relationship between interdigestive phase of gastric secretion and behavior in chronic fistula rats. Amer. J. Med. Sci., 1962, Vol. 243, p. 679-680. (Abst.)

101. Shay H., Bralow S.P., Komarov S.A., Kessler W.B. Effect of complete adrenalectomy on gastric secretion and parietal cell mass in Wistar rats. Fed. Proc., 1962, Vol. 21, p. 265. (Abst.)

\section{3}

102. Bralow S.P., Shay H., Komarov S.A. Effect of hypothyroidism induced by radioactive iodine on gastric secretion in chronic fistula rats.//Program of AGA Annual Meeting. 1963. (Abst.).

103. Bralow S.P., Komarov S.A., Shay H. Effect of total adrenalectomy on gastric secretion in chronic gastric fistula rats. Amer. J. Physiol., 1963, Vol. 206, p. 1309-1314.

104. Bralow S.P., Komarov S.A., Shay H., Boyd E. Relationship between gastric secretion and behavior in chronic gastric fistula rats. Amer. J. Physiol., 1963, Vol. 205, p. 230-234.

105. Komarov S.A., Schoenfield L.J., Siplet H. Effect of a gastrin preparation on gastric secretion in chronic fistula rats. Physiologist, 1963, Vol. 6, p. 218. (Abst.)

106. Komarov S.A., Bralow S.P., Boyd E. A Permanent rat gastric fistula. Proc. Soc. Exp. Biol. and Med., 1963, Vol. 112, p. 451-453.

107. Komarov S.A., Bralow S.P., Shay H., Boyd E. Relationship between gastric secretion and behavior in chronic fistula rats. Amer. J. Physiol., 1963, Vol. 205, p. 230-234.

\section{4}

108. Bralow S.P., Komarov S.A., Shay H. Effect of total adrenalectomy on gastric secretion in chronic gastric fistula rats. Amer. J. Med. Sci., 1964, Vol. 247, p. 117. (Abst.)

109. Bralow S.P., Komarov S.A., Shay H. Effect of total adrenalectomy on gastric secretion in chronic gastric fistula rats. Amer. J. Physiol., 1964, Vol. 206, p. 1309-1314.

110. ${ }^{*}$ Bralow S.P., Komarov S.A. and Shay H. Effect of thyroid activity on gastric secretion in chronic fistula rats. Physiologist, 1964, Vol. 7, p. 92. (Abst).

\section{6}

111. Bralow S.P., Komarov S.A. and Shay H. Effect of thyroid activity on gastric secretion in adult fistula rats. Amer. J. Dig. Dis., 1966, Vol. 11, p. 142-154. 
112. Marks I.N., Komarov S.A. and Shay H. Influence of cholinergic stimuli on gastric secretory responses to histamine in the dog. Amer. J. Dig. Dis., 1966, Vol. 11, p. 122-141.

113. Schoenfield L.J., Siplet H. and Komarov S.A. Effect of a gastrin preparation on gastric secretion in chronic fistula rats. Amer. J. Dig. Dis., 1966, Vol. 11, p. 113-121.

\title{
Doctor of medicine of Latvian University S. A. Komarov (1892-1964) (Summary)
}

\author{
By K. G. Vasilyev, A. Vīksna, V. Garbuzova
}

The article covers life and activities of the physiologist and biochemist S. A. Komarov. He was born in Lugansk (at present Ukraine). His higher medical education started in the Military medical academy (St Petersburg) and later he graduated from Kharkov University. His scientific activities took place at Kharkov (1915-1922) and Latvian (1922-1929) Universities under the guidance of the professor R. Krimberg (1874-1941) as well as McGill University (1930-1942) in Montreal, under the guidance of the professor B. P. Babkin (1877-1950). Thereupon he engaged in studies in the School of medicine of the Temple University (1942-1964) in Philadelphia. He died namely here.

Константин Георгиевич Васильев,

профессор Сумского Государственного университета

vasylyev_sumy@ukr.net

\section{Арнис Виксна,}

профессор Латвийского Университета

arnis.viksna@lu.lv

Виктория Юрьевна Гарбузова,

доцент Сумского Государственного университета 